University of Nebraska - Lincoln

DigitalCommons@University of Nebraska - Lincoln

\title{
Effect of Formulation and Tillage Practice on Volatilization of Atrazine and Alachlor
}

\author{
Brian J. Wienhold \\ University of Nebraska-Lincoln, Brian.Wienhold@ars.usda.gov \\ Timothy J. Gish \\ USDA-ARS
}

Follow this and additional works at: https://digitalcommons.unl.edu/usdaarsfacpub

Wienhold, Brian J. and Gish, Timothy J., "Effect of Formulation and Tillage Practice on Volatilization of Atrazine and Alachlor" (1994). Publications from USDA-ARS / UNL Faculty. 1200.

https://digitalcommons.unl.edu/usdaarsfacpub/1200

This Article is brought to you for free and open access by the U.S. Department of Agriculture: Agricultural Research Service, Lincoln, Nebraska at DigitalCommons@University of Nebraska - Lincoln. It has been accepted for inclusion in Publications from USDA-ARS / UNL Faculty by an authorized administrator of DigitalCommons@University of Nebraska - Lincoln. 


\title{
Effect of Formulation and Tillage Practice on Volatilization of Atrazine and Alachlor
}

\author{
Brian J. Wienhold* and Timothy J. Gish
}

\begin{abstract}
Conservation tillage practices are being implemented by many farmers to conserve water and soil resources. These practices may modify the soil surface in ways that differentially effect dissipation of pesticide when compared to conventionally tilled fields. We measured volatilization of atrazine [2-chloro-4-ethylamino-6-isopropylamino-s-triazine] and alachlor [2-chloro-2'-6'-diethyl-n-(methoxymethyl) acetanilide] applied as either an experimental starch-encapsulated formulation or as a commercial formulation, containing atraxine as a wettahle powder and microencapsulated alachlor, to adjacent no-till and conventionally tilled corn fields in Maryland. Both formulations were applied at the same rate; $1.7 \mathrm{~kg}$ $\mathrm{ha}^{-1}$ for atrazine and $2.8 \mathrm{~kg} \mathrm{ha}^{-1}$ for alachlor. After $35 \mathrm{~d}$, cumulative volatilization of alachlor from conventionally tilled fields was $14 \%$ of that applied for both formulations. Cumulative volatilization of alachlor was less from no-till fields with $9 \%$ of the commercial formulation and $4 \%$ of the starch-encapsulated formulation being lost. After $35 \mathrm{~d}$, cumulative volatilization of the commercial formulation of atrazine from the conventionally tilled field was $9 \%$ of that applied compared with $4 \%$ of that applied to the no-till field. Starch encapsulation reduced volatiliza-
\end{abstract}

USDA-ARS, Hydrology Lab., Natural Resources Institute, Beltsville, MD 20705. Received 1 June 1993. *Corresponding author.

Published in J. Environ. Qual. 23:292-298 (1994). tion losses of atrazine to $<2 \%$ of that applied for both tillage practices. Starch encapsulation appears to be a viahle formulation modification for reducing volatilization losses of herbicides, especially from no-till fields.

$I$

N AN EFFORT to conserve soil and water resources, conservation tillage practices are being implemented on a wide scale (Christensen and Norris, 1983). No-till is the most extreme form of conservation tillage in that the soil is never tilled and plant residue is allowed to accumulated on the soil surface (Soil Conservation Society of America, 1982). While no-till conserves water and soil, larger inputs of pesticides are often necessary to maintain favorable crop yields (Christensen and Norris, 1983). In addition, the environmental fate of a pesticide applied to a no-till field may be very different than that of a pesticide applied to a conventionally tilled field (Glotfelty, 1987; Helling, 1987).

Volatilization is one pesticide dissipation pathway that may be affected by no-till practices. Pesticides volatilization from soil is controlled by: chemical properties of the pesticide (vapor pressure and solubility), mode of application (surface application vs. incorporated, and formula- 
tion), and soil properties (soil temperature, soil moisture distribution, and soil organic matter content) (Glotfelty and Schomburg, 1989). With the exception of chemical properties of the pesticide, all of these factors may be quite different when comparisons between no-till fields are made with conventionally tilled fields (Glotfelty, 1987).

Since no-till does not allow for any tillage, unless the pesticide is injected into the seed row, pesticides must be surface-applied. A large portion of surface-applied pesticides may be intercepted by the plant residue in no-till fields (Ghadiri et al., 1984). This crop residue will have a much larger surface area and will be rougher than a bare soil surface, resulting in greater volatilization losses (Glotfelty and Schomburg, 1989). Granular formulations and that portion of liquid formulations that penetrates through the plant residue to the underlying soil during application or that is washed from plant residue by precipitation after application will be in a very different microenvironment than formulations applied to conventionally tilled soils.

Surface soil under no-till crop residue is usually moister, cooler, and has a greater organic matter content than surface soil under conventional tillage (Thomas and Frye, 1984). Pesticide volatilization is greater from moist soil surfaces than from dry soil surfaces and will be less from cool soil surfaces than from warm soil surfaces (Spencer et al., 1973). Increased soil organic matter content increases pesticide adsorption and decreases volatilization (Spencer and Cliath, 1974). Since surface soil conditions under notillage are very different than those under conventional tillage and these conditions affect pesticide volatilization differentially, the net effect of no-till on pesticide volatilization is largely unknown. Few field studies assessing tillage effects on volatilization losses of pesticides have been conducted (Whang et al., 1993).

Volatilization losses of agriculturally applied chemicals can be measured by a number of methods. Disappearance methods involve determination of the mass of chemical lost from soil samples collected over some time interval. Unless sampling is extensive, the uncertainty associated with this method can be large when more than one dissipation pathway exists and when spatial variability at the study site is large. Micrometeorological methods include several techniques in which chemical concentration, windspeed, and temperature gradients are simultaneously measured and used to calculate the chemical vapor flux from the field (Parmele et al., 1972; Harper, 1988; Glotfelty and Schomburg, 1989; Taylor and Spencer, 1990). A potential problem with these methods is the large area needed for each study site ( 60 to $200 \mathrm{~m}$ in diam. plus buffer strips). Soils and meteorological conditions may be quite different at sites separated by these distances; these factors may become confounding variables when comparisons among treatments are being made. Enclosure methods are a third approach for measuring volatilization (Harper, 1988). Enclosures do not require large field areas and are relatively simple; however, care must be used to ensure that modification of soil surface conditions is minimized by the presence of the enclosures.

Increased awareness that agriculturally applied chemicals are potential sources for environmental contamination has encourage development of new formulations that may modify the behavior of pesticides. Encapsulation procedures are a formulation modification which modify pesticide behavior. Microencapsulation of chloropropham [isopropyl m-chlorocarbanilate] in nylon capsules reduced volatilization losses five-fold when compared with chloropropham applied as emulsified concentrate (Turner et al., 1978). A method that may modify pesticide behavior and is receiving increased attention involves encapsulating the chemical in a starch matrix (Wing et al., 1987). Schreiber et al. (1987) suggested that starch encapsulation should reduce volatilization losses of herbicides by controlling the rate at which the chemical is released into the soil environment. A greenhouse study compared volatilization losses from moist soils at three temperatures and found that starch encapsulation reduced volatilization losses of atrazine but increased or did not affect volatilization of alachlor (Wienhold et al., 1993). The effect of starch encapsulation on volatilization in the field, where temperatures fluctuate and soil surface moisture conditions vary, has not been studied.

We used chambers, similar in design to the agroecosystem chambers of Nash et al. (1977), to measure cumulative volatilization losses of two commonly used agricultural herbicides, atrazine and alachlor. Herbicides were applied as either an experimental starch-encapsulated formulation or as a commercial formulation to adjacent notill and conventionally tilled fields.

\section{MATERIALS AND METHODS}

Volatilization was measured from four 0.25 -ha fields, two notill and two conventionally tilled, on the Central Maryland Research and Education Center near Upper Marlboro, MD. The Monmouth sandy loam (clayey, mixed, mesic Typic Hapludult) present at the site has a pH of 6.4 , an organic matter content of $1.1 \%$, and a clay content of $5.6 \%$. Since 1989 , all four fields have been planted in corn (Zea mays L.) with a winter cover crop of rye (Secale cereale L.). Corn residue was left on all the fields during the winter; rye was cut in the spring, 1 to 2 wk prior to planting. Crop residues were then incorporated into the soil with a chisel plow on the conventionally tilled fields but remained on the surface of the no-tillage treatment. There is $>50 \%$ residue cover on the no-till fields (Walter J. Rawls, 1992, personal communication).

Atrazine and alachlor was applied as either commercial formulation (Bullet, Monsanto Co., St. Louis, $\mathrm{MO}^{1}$ ) or starchencapsulated (Carr et al., 1991). The commercial formulation contained atrazine as a wettable powder and microencapsulated alachlor. Starch-encapsulated atrazine contained $11.1 \%$ and alachlor contained $10.1 \%$ a.i. Starch granules 0.4 to $1.2 \mathrm{~mm}$ in diam. were used. Both formulations were applied at the same rate; 1.7 $\mathrm{kg} \mathrm{ha}^{-1}$ for atrazine and $2.8 \mathrm{~kg} \mathrm{ha}^{-1}$ for alachlor. The starchencapsulated herbicides were broadcast onto the soil surface of two fields, one of each tillage practice. The commercial formulation was sprayed onto the soil surface of the other two fields.

Volatilization of atrazine and alachlor was measured using 0.25 $\mathrm{m}^{3}$ acrylic chambers that sampled the atmosphere above $0.5 \mathrm{~m}^{2}$ of each field (Fig. 1). These chambers were designed and constructed to specifications similar to the agroecosystem chambers of Nash et al. (1977), which have been used extensively to evalu-

\footnotetext{
${ }^{1}$ Trade names or company names are included for the benefit of the reader and imply no endorsement or preferential treatment of the product listed by the U.S. Department of Agriculture.
} 


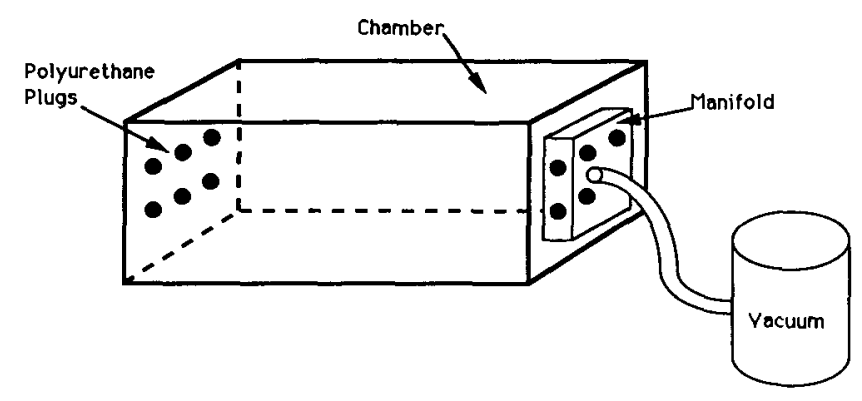

Fig. 1. Schematic drawing of chambers used to measure herbicide volatilization in the field.

ated the volatilization behavior of a number of pesticides (Nash, 1983a,b,c; Nash and Gish, 1989; Wienhold et al., 1993).

The open-bottom chambers, one per field, were pressed into the soil $\approx 10 \mathrm{~cm}$ ) and air was drawn through each chamber using a vacuum cleaner (Dayton Electric Co., Chicago, IL) attached to a manifold at the exit end of each chamber (Fig. 1). Air was drawn through each chamber at a rate of $31.5 \pm 0.9 \mathrm{~L} \mathrm{~min}^{-1}$ $\left(5.25 \mathrm{~L} \mathrm{~min}^{-1} \mathrm{plug}^{-1}\right)$. This flow rate resulted in complete exchange of air within the chamber every $8 \mathrm{~min}$ and corresponds to a wind speed of $8 \mathrm{~m} \mathrm{~h}^{-1}$. Air entered the chamber through six evenly-spaced holes $(5 \mathrm{~cm}$ diam.) present on the front $(0.5 \mathrm{~m}$ by $0.5 \mathrm{~m}$ ) wall, passed the length of the chamber $(1.0 \mathrm{~m})$, and exited through six evenly-spaced holes present on the back wall of the chamber. Each air entry and exit hole contained a polyurethane foam plug $(5 \mathrm{~cm}$ by $5 \mathrm{~cm} \mathrm{dia}$.) to trap herbicide present in the vapor phase (Turner and Glotfelty, 1977). Polyurethane foam plugs quantitatively trap pesticides from up to $6.3 \times$ $10^{4} \mathrm{~L}$ of air (Turner and Glotfelty, 1977). Polyurethane foam plugs in entrance holes removed herbicide present in the incoming air. Polyurethane foam plugs in exit holes trapped herbicide which volatilized from the field under the chamber. Chambers were moved often (every 1 to $3 \mathrm{~d}$ ) to insure that soil surface conditions inside the chambers were representative of those in the field being sampled. Special care was taken to move the chambers as soon after precipitation events as possible. A new location was selected each time the chamber was moved so that no part of the field was repeatedly sampled.

Sampling was initiated within $5 \mathrm{~min}$. of herbicide application on June 3, 1992. Polyurethane foam plugs were replaced 1, 2, $5,8,12,16,21,28$, and $35 \mathrm{~d}$ after herbicide application. Polyurethane foam plugs were soxlet-extracted with $150 \mathrm{~mL}$ of ethyl acetate for $3 \mathrm{~h}$. The extract was then evaporated to dryness and redissolved in $10 \mathrm{~mL}$ of ethyl acetate. Concentrations of atrazine, and alachlor were quantified using gas chromatography.

The effect of the chambers on soil surface conditions was assessed by comparing soil surface temperature and water content for a plot under the chamber to that of an adjacent plot over a 3-d period. Soil temperature was determined by inserting a temperature probe (Type NP penetration probe, OMEGA Engineering, Stamford, CT) into the 0 - to 3 -cm soil layer at two locations in each plot. Soil moisture was determined gravimetrically (Gardner, 1986) by collecting three surface samples $(0-3 \mathrm{~cm})$ from each plot at five times over the 3 -d period.

Five surface $(0$ to $5 \mathrm{~cm})$ soil samples were collected from each field $15 \mathrm{~min}$ after herbicide application and again 8 and $35 \mathrm{~d}$ after herbicide application. Soil samples were collected by pressing a soil can (sample area of $38.5 \mathrm{~cm}^{2}$ ) $5 \mathrm{~cm}$ into the soil and removing the soil. Soil samples were pretreated with a phosphate buffer solution containing amylase (Wienhold and Gish, 1991) to facilitate release of the herbicides from starch granules. Following this pretreatment sufficient methanol was added to give a final ratio of methanol/water of $4: 1$ by volume. Samples were placed on a wrist action shaker for $1 \mathrm{~h}$ and suction filtered through glass fiber filter paper. Methanol was removed from the filtrate by rotoevaporation and atrazine and alachlor were isolated from the remaining aqueous solution by solid-phase extraction (Nash, 1990). Concentrations of atrazine and alachlor were quantified using gas chromatography.

Operating conditions of the gas chromatograph were: $30 \mathrm{~m}$ by $0.32 \mathrm{~mm}$ fused silica capillary column coated with $0.26 \mu \mathrm{m}$ SPB-5 (Supelco, Bellefonte, PA); injector temperature of $200^{\circ} \mathrm{C}$, oven temperature of $150^{\circ} \mathrm{C}$ and a N-P detector operating at a temperature of $220^{\circ} \mathrm{C}$; He carrier gas at $2.5 \mathrm{~mL} \mathrm{~min}^{-1}$. Trifluralin [ $\alpha, \alpha, \alpha$-trifluro-2,6-dinitro- $N, N$-dipropyl- $p$-toluidine] was used as an internal standard.

\section{RESULTS AND DISCUSSION}

Air temperature ranged from 7 to $32^{\circ} \mathrm{C}$ with an average daily high of $27^{\circ} \mathrm{C}$ and an average daily low of $15^{\circ} \mathrm{C}$ (Fig. 2 ). The study site received measurable precipitation on $13 \mathrm{~d}$ of the $35 \mathrm{~d}$ study, the first rain events occurred 2 and $3 \mathrm{~d}$ after herbicide application. Cumulative rainfall over the $35 \mathrm{~d}$ study measured $10.6 \mathrm{~cm}$ (Fig. 2). Wind speed averaged $350 \mathrm{~m} \mathrm{~h}^{-1}$ during the $35 \mathrm{~d}$ study; however, this average was strongly influenced by several windy days toward the end of the study. Average wind speed during the first $20 \mathrm{~d}$ of the study was $7 \mathrm{~m} \mathrm{~h}^{-1}$.

Differences between soil surface temperature inside a chamber of those of an adjacent plot were never more than $1.5^{\circ} \mathrm{C}$ (Fig. 3A). Soil surface temperatures inside the chamber were consistently the same or cooler than those outside the chamber. Changes in soil surface water content inside the chamber were similar to those outside the chamber (Fig. 3B). During Day 1, 43 g water kg soil ${ }^{-1}$ was lost from the surface soil layer inside the chamber compared with $49 \mathrm{~g}$ water $\mathrm{kg} \mathrm{soil}^{-1}$ from the surface soil layer outside the chamber. Precipitation fell on the site during the evening of Day 1 and the chambers were moved to a new plot. During Days 2 and 3, $39 \mathrm{~g}^{\text {water }} \mathrm{kg} \mathrm{soil}^{-1}$ were lost from the surface soil layer inside the chamber compared with $38 \mathrm{~g}$ water $\mathrm{kg}$ soil $^{-1}$ from the surface layer outside the chamber. These results suggest that air flow through the chamber was sufficient to prevent heat buildup within the chamber and that evaporative losses of water from the soil were not greatly modified by the chamber.

Variation in the mass of herbicide trapped by the poly-

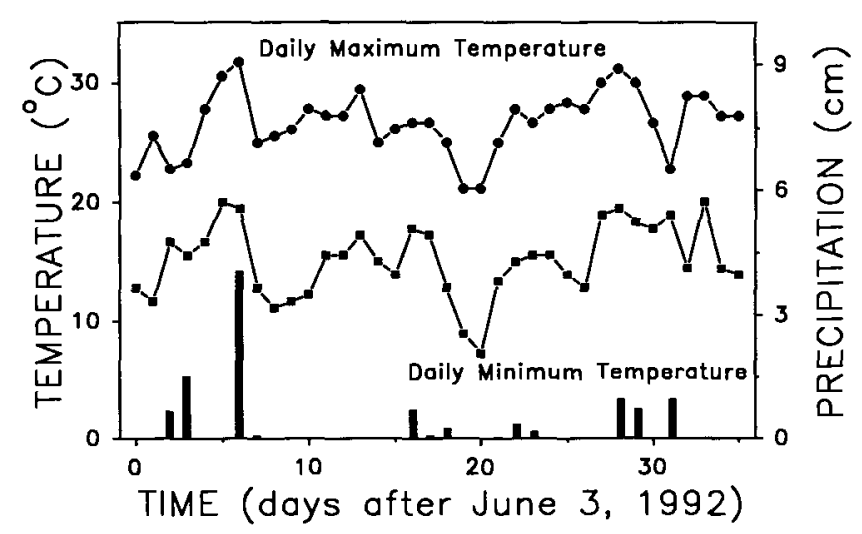

Fig. 2. Daily maximum and minimum temperature, and daily precipitation received at the Central Maryland Research and Education Center near Upper Marlboro, MD. 


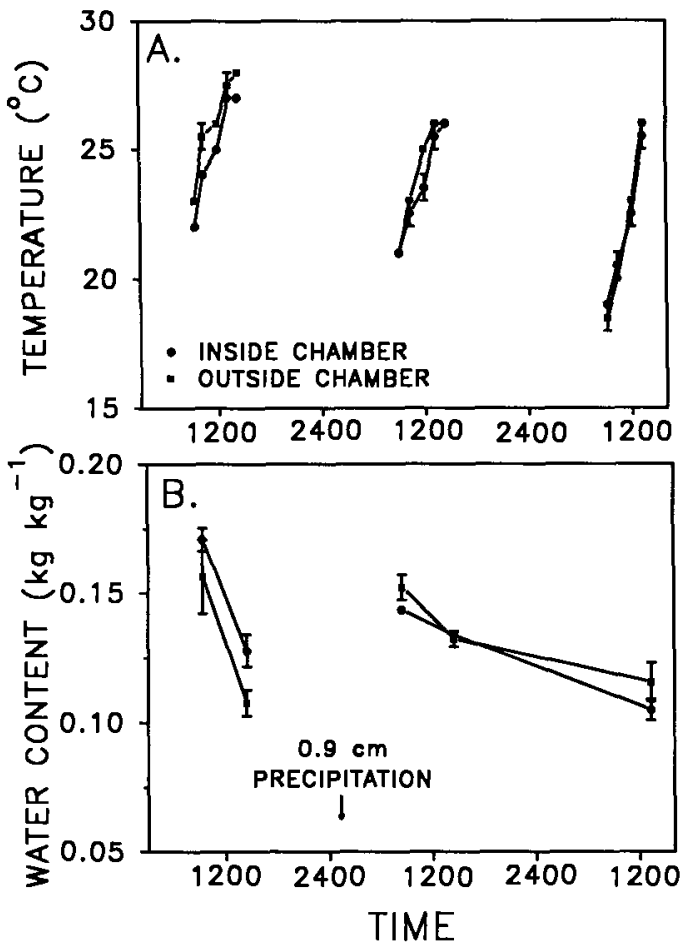

Fig. 3. Comparison of $(A)$ temperature and $(B)$ and water content for the soil surface layer $(0 \mathrm{to} 3 \mathrm{~cm})$ of a plot under a volatilization chamber to that of an adjacent plot.

urethane foam plugs was quite uniform among the six plugs in each chamber for each sample period (CV $<50 \%$ in 62 out of 72 sets of polyurethane foam plugs) suggesting that air flow was sufficient to insure thorough mixing of the air as it is passed through the chambers. Ideally the air speed through the chamber should be similar to the wind speed over the field. During the first $20 \mathrm{~d}$ of this study, when volatilization rates were highest, the air speed through the chamber $\left(8 \mathrm{~m} \mathrm{~h}^{-1}\right)$ was similar to the wind speed over the field $\left(7 \mathrm{~m} \mathrm{~h}^{-1}\right)$. During the last 2 wks of the study there were several windy days when wind speeds over the field were much greater than the air speed through the chamber. However, after $20 \mathrm{~d}$, concentrations of the herbicides at the soil surface were much reduced (Fig. 4B and 5B) and the corn canopy had become established making it unlikely that this discrepancy had a significant effect on the results. Cumulative volatilization measured using these chambers agrees well with results from studies using the aerodynamic (Glotfelty et al., 1989), theoretical profile (Whang et al., 1993) and greenhouse (Wienhold et al., 1993) methods.

At early times ( $<8 \mathrm{~d})$, alachlor (Fig. 4A) and atrazine (Fig. 5A) volatilization rates from all fields were the greatest of those observed. After $8 \mathrm{~d}$, volatilization rates declined (i.e., the slope of the lines in Fig. 4A and 5A approaches zero) reflecting the diluted surface concentrations of alachlor (Fig. 4B) and atrazine (Fig. 5B). Eight days after application, the surface concentration of alachlor was one-third the surface concentration on the day of application and declined to $<25 \%$ of that applied by Day 35 (Fig. 4B). Neither formulation nor tillage appeared to influence soil

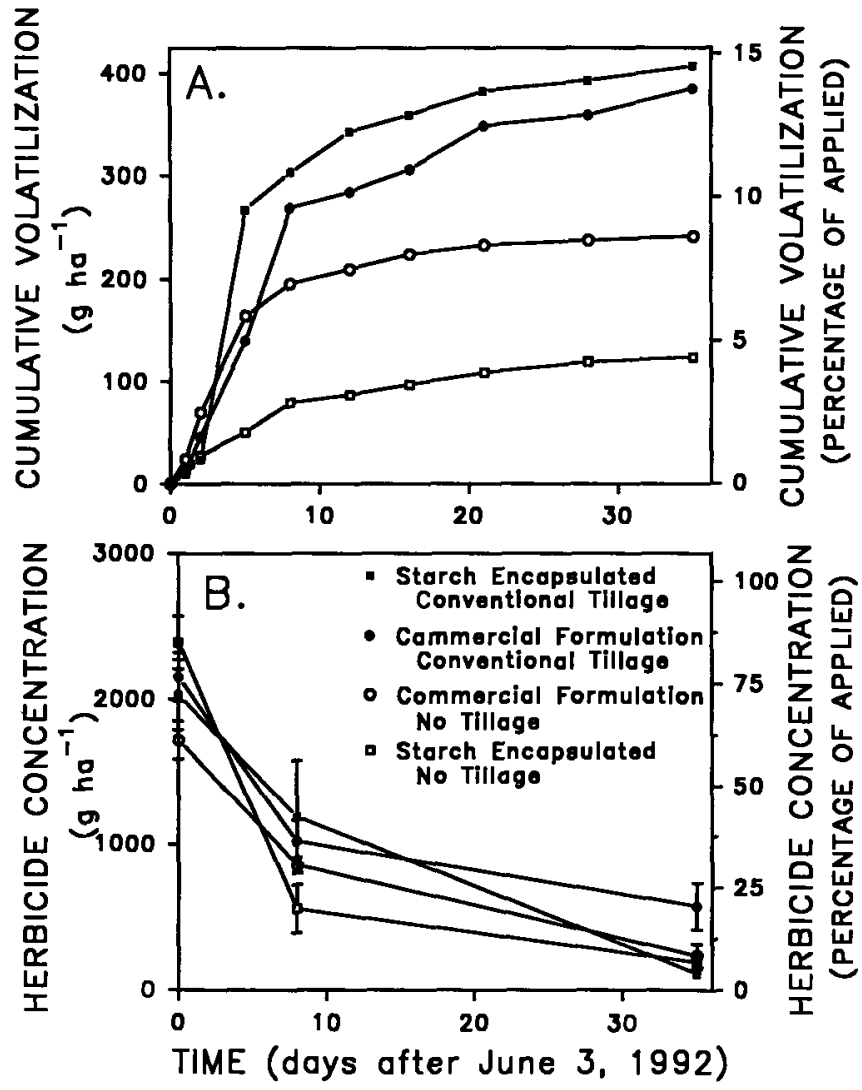

Fig. 4. $(A)$ Cumulative volatilization and $(B)$ surface concentration $(0$ to $5 \mathrm{~cm}$ ) of alachlor applied as a commercial formulation or as a starchencapsulated formulation to conventionally tilled or no-till fields.

surface concentrations of alachlor after $35 \mathrm{~d}$. In contrast, formulation appears to influence soil surface concentrations of atrazine. After 35 days, $<25 \%$ of commercially formulated atrazine remained in the surface layer, while $50 \%$ of the starch-encapsulated atrazine remained in the surface layer (Fig. 5B). Lesser surface concentrations 8 and $35 \mathrm{~d}$ after application are the result of volatilization losses form the fields, degradation losses of chemical, and leaching of the chemical into the soil profile.

At early times $(<5 \mathrm{~d})$ volatilization losses of commercially formulated alachlor (Fig. 4A) and atrazine (Fig. 5A) were greater from the no-till field than from the conventionally tilled field. After the precipitation events of the first week (Fig. 2) volatilization losses of alachlor (Fig. 4A) and atrazine (Fig. 5A) were greater from the conventionally tilled field than from the no-till field. From Day 10 to Day 35 volatilization rates declined and were similar between the two fields reflecting the lesser surface concentrations of alachlor (Fig. 4B) and atrazine (Fig. 5B) in these fields.

After $35 \mathrm{~d}$, cumulative volatilization losses of commercial formulation were $14 \%$ for alachlor and $9 \%$ for atrazine of that applied to conventionally tilled fields. When applied to no-till fields, volatilization losses of commercial formulation were $9 \%$ of that applied for alachlor and $4 \%$ of that applied for atrazine. These losses are consistent with differences in vapor density of these two chemi- 

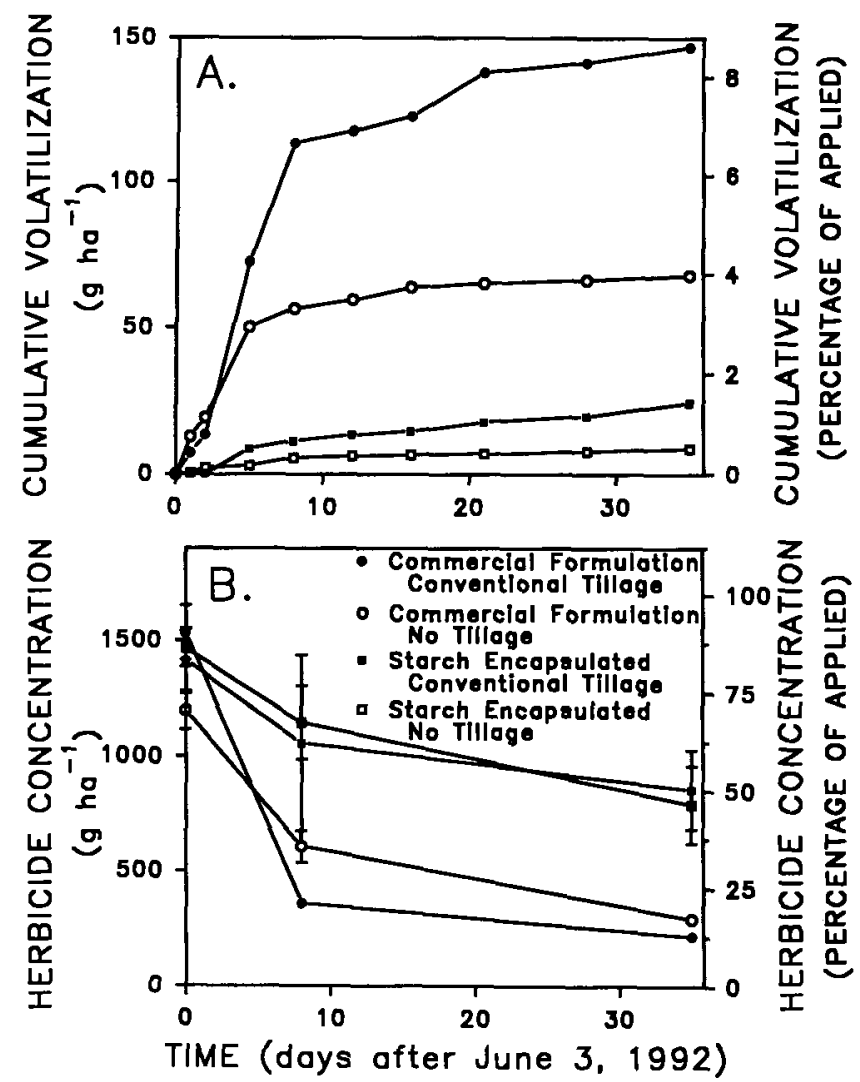

Fig. 5. $(A)$ Cumulative volatilization and $(B)$ surface concentration $(0$ to $5 \mathrm{~cm}$ ) of atrazine applied as a commercial formulation or as a starchencapsulated formulation to conventionally tilled or no-till fields.

cals (320 $\mathrm{ng} \mathrm{L}^{-1}$ for alachlor and $8 \mathrm{ng} \mathrm{L}^{-1}$ for atrazine at $25^{\circ} \mathrm{C}$ ).

Glotfelty et al. (1989) reported losses of commercial formulation alachlor of $19 \%$ and atrazine of $2 \%$ of that applied to a fallow field after $21 \mathrm{~d}$. Earlier we reported volatilization losses of surface applied commercial formulation alachlor of $10 \%$ and atrazine of $8 \%$ after $35 \mathrm{~d}$ at $25^{\circ} \mathrm{C}$ (Wienhold et al. , 1993). Measured volatilization losses of commercially formulated alachlor and atrazine from the conventionally tilled field appear reasonable if differences in temperature between our earlier study and the present study (average daily high temperature of $27^{\circ} \mathrm{C}$ ) and differences in temperature and soil properties between the present study and that of Glotfelty et al. (1989; average daily high temperature of $30^{\circ} \mathrm{C}$ ) are considered. Whang et al. (1993) calculated cumulative (after $26 \mathrm{~d}$ ) volatilization losses of atrazine of 1 to $2 \%$ of that applied from adjacent no-till and conventionally tilled plots. Results from the present study are slightly greater than the results of Whang et al. (1993), however, their study was conducted $45 \mathrm{~d}$ earlier in the growing season and temperatures during the first week of their study (when most volatilization occurs) were $\approx 10^{\circ} \mathrm{C}$ cooler than the first week of our study. The study of Whang et al. (1993) is the only other side-by-side comparison of volatilization of atrazine that we are aware of and we have been unable to find any similar comparisons of volatilization of alachlor from no-till and conventionally tilled fields.
Volatilization losses of starch-encapsulated alachlor (Fig. 4A) and atrazine (Fig. 5A) from the no-till field were similar to those from the conventionally tilled field at early times $(<3 \mathrm{~d})$. Before precipitation fell at the site, the starchencapsulated herbicides were largely retained within the starch granules and little volatilization occurred. After precipitation on Days 2 and 3, the starch granules imbibed water and released of the herbicides increased. From Days 3 to 8 , volatilization losses of starch-encapsulated alachlor from the conventionally tilled field were much greater than volatilization losses of starch-encapsulated alachlor from the no-tilled field (Fig. 4A). From 8 to $35 \mathrm{~d}$, volatilization rates declined and were similar between the two fields reflecting the relative surface concentrations of alachlor in these fields (Fig. 4B). After $35 \mathrm{~d}$, cumulative volatilization of starch-encapsulated alachlor was $14 \%$ of that applied to conventionally tilled fields and $4 \%$ of that applied to no-till fields (Fig. 4A). Volatilization losses of starch encapsulated atrazine were much less than those of alachlor. After $35 \mathrm{~d}$, cumulative volatilization of starchencapsulated atrazine was $<2 \%$ of that applied to the conventionally tilled field and $<1 \%$ of that applied to the no-till field (Fig. 5A).

Formulation affected volatilization of these two herbicides differently. Starch encapsulation did not affect volatilization of alachlor (Fig. 4A) but substantially reduced volatilization of atrazine (Fig. 5A) from conventionally tilled fields when compared to the commercial formulation. We attribute this differential response to differences in release characteristics of these formulations. Alachlor is much more soluble in water $\left(240 \mathrm{mg} \mathrm{L}^{-1}\right)$ than is atrazine $(32 \mathrm{mg}$ $\left.\mathrm{L}^{-1}\right)$. Alachlor is released more quickly from the starch matrix ( $8 \mathrm{~d}$ ) than is atrazine (21 d) when applied to moist soils (Wienhold and Gish, 1992). Slower release provides a longer period of time for the chemical to diffuse into the surrounding soil where it can be absorbed, thereby making it less susceptible to leaching and volatilization. The similarity in volatilization losses of alachlor between the two formulations on conventionally tilled fields may be due to similar release rates between the microencapsulated commercial formulation and the starch encapsulated formulation.

Starch encapsulation reduced volatilization losses of both herbicides from no-till fields when compared to commercial formulation. Plant residue likely intercepted a portion of the commercial formulation during the application process. Ghadiri et al. (1984) found that $60 \%$ of commercial formulation atrazine was intercepted by wheat (Triticum aestivum L.) stubble during application. The greater surface area and roughness of the plant residue will likely result in greater volatilization losses from no-till fields than from conventionally tilled fields receiving commercially formulated herbicides until precipitation washes the chemical from the crop residue on to the underlying soil (Glotfelty, 1987; Glotfelty and Schomburg, 1989). Others have found that from 60 to $90 \%$ of the herbicide intercepted by plant residue is washed on to the underlying soil by precipitation (Martin et al., 1978; Lowder and Weber, 1979; Ghadiri, et al., 1984). Washoff of herbicide from plant residue is dependent on how soon after application rainfall occurs. Greater washoff of intercepted herbicides occurs 
during rain events which closely follow application of the herbicide (Martin et al., 1978; Lowder and Weber, 1979).

Starch-encapsulated herbicides were probably not intercepted by plant residue in the no-till fields. Following release of the herbicides from the starch matrix, differences in volatilization between the two tillage practices were likely due to differences in boundary layer conditions of the fields. In the conventionally tilled field there is a small stagnant boundary layer present between the soil surface and the ambient atmosphere for the chemical to diffuse through while in the no-till field accumulated crop residue produces a much thicker stagnant boundary layer through which the chemical must diffuse (Glotfelty, 1987; Glotfelty and Schomburg, 1989).

Differences in cumulative volatilization between tillage practices and formulations appears largely due to events occurring during the first week. Under different environmental conditions results may be substantially different. Volatilization of commercially formulated herbicides was greater from no-till fields than from conventionally tilled fields until sufficient precipitation was received on the site to wash the herbicide from the plant residue of the no-till fields to the underlying soil. After the initial precipitation events, volatilization losses of commercially formulated herbicides were greater from conventionally tilled fields than from no-till fields due to boundary layer conditions discussed above. If precipitation events had occurred at a different time, it seems likely that the results of this study would have been altered. If precipitation had occurred immediately after herbicide application the chemical would have been washed from the plant residue earlier and differences in cumulative losses between tillage practices would have been greater. Similarly, if precipitation events had occurred much later after herbicide application, volatilization losses from plant residue at early times would have been greater and differences in cumulative losses between tillage practices may have been less.

Comparing the percentage of applied herbicide recovered in the vapor phase (Fig. 4A and 5A) to the percentage of applied herbicide which has dissipated from the surface soil layer (Fig. 4B and 5B) suggests that volatilization is not the main dissipation pathway for alachlor or atrazine. However, volatilization losses result in pesticides entering parts of the environment where they were not intended. Pesticides present in the atmosphere contaminate surface water and soil by washout during precipitation, fallout of particulate material to which the pesticide has become adsorbed, and by direct exchange between the atmosphere and the surface. Atrazine and alachlor were the two most commonly detected pesticides in precipitation in Iowa (Nations and Hallberg, 1992) and Glotfelty et al. (1990) estimated that atrazine entering the Chesapeake Bay in washout and fallout was $\approx 10 \%$ of that entering the bay in runoff. Hence, volatilization losses are an environmental concern and reducing these losses is desirable.

Starch encapsulation reduced volatilization of atrazine from the conventionally tilled field and reduced volatilization of both alachlor and atrazine from the no-till field but did not effect volatilization of alachlor from the conventionally tilled field. Starch encapsulation may reduce herbicide losses during the application procedure when sub- stantial amounts of herbicide may be lost to volatilization and drift (Himel et al., 1990; Taylor et al., 1977). Possible reductions in application losses and volatilization losses from no-till fields suggests that starch-encapsulated may be a viable formulation modification for reducing herbicide losses to the atmosphere.

\section{ACKNOWLEDGMENTS}

The authors thank Lynn McKee and Kathy Ketteridge for laboratory assistance; Mark Spicknall and Alfred Hawkins for field assistance; Adel Shirmohammadi for providing access to the study site; Marvin Schreiber for supplying the starch encapsulated herbicides; Charles Helling, Richard Pfeiffer, Marvin Schreiber, William Spencer, and Scott Yates for commenting on the manuscript; and the Weed Science and Pesticide Degradation Laboratories at Beltsville, MD, for providing access to laboratory facilities.

\section{REFERENCES}

Carr, M.E., R.E. Wing, and W.M. Doane. 1991. Encapsulation of atrazine within a starch matrix by extrusion processing. Cereal Chem. 68:262-266.

Christensen, L.A., and P.E. Norris. 1983. A comparison of tillage systems for reducing soil erosion and water pollution. Agric. Econ. Rep. no. 499, USDA, Washington, DC.

Gardner, W.H. 1986. Water content. p. 493-544. In A. Klute (ed.) Methods of soil analysis. Part 1. 2nd ed. Agron. Monogr. 9. ASA and SSSA, Madison, WI.

Ghadiri, H., P.J. Shea, and G.A. Wicks. 1984. Interception and retention of atrazine by wheat (Triticum aestivum L.) stubble. Weed Sci. 32:24-27.

Glotfelty, D.E. 1987. The effects of conservation tillage practices on pesticide volatilization and degradation. p. 169-177. In T.J. Logan (ed.) Effects of conservation tillage on groundwater quality: Nitrates and pesticides. Lewis Publ., Chelsea, MI.

Glotfelty, D.E., M.M. Leech, J. Jersey, and A.W. Taylor. 1989. Volatilization and wind erosion of soil surface applied atrazine, simazine, alachlor, and toxaphene. J. Agric. Food Chem. 37:546-551.

Glotfelty, D.E., and C.J. Schomburg. 1989. Volatilization of pesticides from soil. p. 181-207. In B.L. Sawhney and K. Brown (ed.) Reaction and movement of organic chemicals in soils. SSSA Spec. Publ. 22, ASA and SSA, Madison, WI.

Glotfelty, D.E., G.H. Williams, H.P. Freeman, and M.M. Leech. 1990. Regional atmospheric transport and deposition of pesticides in Maryland. p. 199-221. In D.A. Kurtz (ed.) Long range transport of pesticides. Lewis Publ., Chelsea, MI.

Harper, L.A. 1988. Comparisons of methods to measure ammonia volatilization in the field. p. 93-109. In B.R. Bock and D.E. Kissel (ed.) Ammonia volatilization from urea fertilizers. Bull. Y-206. National Fertilizer Development Center, Tennessee Valley Authority, Muscle Shoals, AL.

Helling, C.S. 1987. Effect of conservation tillage on pesticide dissipation. p. 179-188. In T.J. Logan et al. (ed.) Effects of convervation tillage on groundwater quality: Nitrates and pesticides. Lewis Publ., Chelsea, MI.

Himel, C.M., H. Loats, and G.W. Bailey. 1990. Pesticide sources to the soil and principles of spray physics. p. 7-50. In H.H. Cheng (ed.) Pesticides in the soil environment: processes, impacts, and modeling. SSSA Book Ser. 2. SSSA, Madison, WI.

Lowder, S.W., and J.B. Weber. 1979. Atrazine retention by crop residues in reduced-tillage systems. Proc. South. Weed Sci. Soc. 32:303-307.

Martin, C.D., J.L. Baker, D.C. Erbach, and H.P. Johnson. 1978. Washoff of herbicides applied to corn residue. Trans. ASAE 21:1164-1168.

Nash, R.G. 1983a. Determining environmental fate of pesticides with microagroecosystems. Residue Rev. 85:199-215.

Nash, R.G. 1983b. Comparative volatilization and dissipation rates of several pesticides from soil. J. Agric. Food Chem. 31:210-217.

Nash, R.G. 1983c. Distribution of butylate, heptachlor, lindane, and dieldrin emulsifiable concentrated and butylate microencapsulated formulations in microagroecosystem chambers. J. Agric. Food Chem. 31:1195-1201. 
Nash, R.G. 1990. Solid phase extraction of carbofuran, atrazine, simazine, alachlor and cyanazine from shallow well water. J. Assoc. Off. Anal. Chem 73:438-442.

Nash, R.G., M.L. Beall, Jr., and W.G. Harris. 1977. Toxaphene and 1,1,1-trichloro-2,2-bis ( $p$-chlorophenyl)ethane (DDT) losses from cotton in an agroecosystem chamber, J. Agric. Food Chem. 25:336-341.

Nash, R.G., and T.J. Gish. 1989. Halogenated pesticide volatilization and dissipation from soil under controlled conditions. Chemosphere 18:2353-2362.

Nations, B.K., and G.R. Hallberg. 1992. Pesticides in Iowa precipitation. J. Environ. Qual. 21:486-492.

Parmele, L.H., E.R. Lemon, and A.W. Taylor. 1972. Micrometeoro-

- logical measurement of pesticide vapor flux from bare soil and corn under field conditions. Water Air Soil Pollut. 1:433-451.

Schreiber, M.M., B.S. Shasha, D. Trimnell, and M.D. White. 1987. Controlled release herbicides. p. 177-191. In C.G. McWhooter and M. Gebhardt (ed.) Methods of applying herbicides. Weed Sci. Soc. Am. Monogr. Ser. WSSA, Champaign, IL.

Soil Conservation Society of America. 1982. Resource conservation glossary. 3rd. ed. Ankeny, IA.

Spencer, W.F., and M.M. Cliath. 1974. Factors affecting vapor loss of trifluralin from soil. J. Agric. Food Chem. 22:987-991.

Spencer, W.F., W.J. Farmer, and M.M. Cliath. 1973. Pesticide volatilization. Residue Rev. 49:1-47.

Taylor, A.W., D.E. Glotfelty, B.C. Turner, R.E. Silver, H.P. Freeman, and A. Weiss. 1977. Volatilization of dieldrin and heptachlor residues from field vegetation. J. Agric. Food Chem. 25:542-548.
Taylor, A.W., and W.F. Spencer. 1990. Volatilization and vapor transport processes. p. 213-269 In H.H. Cheng (ed.) Pesticides in the soil enviroment: Processes, impacts, and modeling. SSSA Book Ser. 2. SSSA, Madison, WI.

Thomas, G.W., and W.W. Frye. 1984. Fertilization and liming, p. 87-126 In R.E. Phillips and S.H. Phillips (ed.) No-tillage agriculture. Van Nostrand Reinhold Co., New York.

Turner, B.C., and D.E. Glotfelty. 1977. Field air sampling of pesticide vapors with polyurethane foam. Anal. Chem. 49:7-10.

Turner, B.C., D.E. Glotfelty, A.W. Taylor, and D.R. Watson. 1978. Volatilization of microencapsulated and conventionally applied chlorpropham in the field. Agron. J. 70:933-937.

Whang, J.M., C.J. Schomburg, D.E. Glotfelty, and A.W. Taylor. 1993. Volatilization of fonofos, chlorpyrifos, and atrazine from conventional and no-till surface soils in the field. J.Environ. Qual. 22:173-180.

Wienhold, B.J., and T.J. Gish. 1991. Enzymatic pretreatment for extraction of starch encapsulated pesticides from soils. Weed Sci. 39: 423-426.

Wienhold, B.J., and T.J. Gish. 1992. Effect of water potential, temperature, and microbial activity on release of starch encapsulated atrazine and alachlor. J. Environ. Qual. 21:382-386.

Wienhold, B.J., A.M. Sadeghi, and T.J. Gish. 1993. Effect of starch encapsulation and temperature on volatilization of atrazine and alachlor. J. Environ. Qual. 22:162-166.

Wing, R.E., S. Maiti, and W.M. Doane. 1987. Effectiveness of jet-cooked pearl cornstarch as a controlled release matrix. Starch/Starke $39: 422-425$. 